https://doi.org/10.46344/jbino.2020.v09i5b.26

\title{
CONCEPTUAL STUDY OF ASHAYAPKARSHA GATI IN SHITTPITTA VYADHI
}

Dr Madhavi D. Gaikwad ${ }^{1}$ Dr Shilpa K .Chatre ${ }^{2}$ \& Dr Dipali J.Aamle 3

Asso.prof of Rog nidan and Vikruti Vigyan Department C.S.M.S.S Ayurved College Aurangabad

HOD and Professor Rog nidan and vikruti vigyan department C.S.M.S.S Ayurved College Aurangabad

ABSTRACT

In Ayurveda, the actual intrinsic factors for Samanyaj Vyadhi are Vata, Pitta and Kapha. These Doshas are susceptible to imbalance and vitiation. In this vitiation or imbalance Doshgati plays important and vital role. Gati means movement and the word Dosha Gati implies movement of Doshas. Types of Dosh Gati are of four types, Koshtha- Shakha -Marmasthisandhi Gati, Vruddhi-Kshaya-Sthana Gati, Urdhwa-AdhaTiryaka Gati and Ashayapkarsha gati. Here Ashayapakarsha means displacement from original place. In this, the vitiated vata dosha displaces normal pitta or kapha from its place. This displacement of pitta and kapha from its place causes various disorders due to imbalance of pitta and kapha. Shitpitta i.e. 'Shita' and 'Pitta' which indicates that these is mainly vitiatioin of 'Vata and Pitta Dosha' in manifestation of 'Shitapitta' but Shitapitta' having 'Vatika Dominency'. 'Prakupita Vata and Kapha \{Pradushtau Kapha Marutau\} due to 'Shita Marutadi Nidana \{Shita Maruta Samsparshat\} - when being 


\section{INTRODUCTION}

According to aim of Ayurveda, knowledge of Dosha (functional forces or factors) is important. Tridosha defines the three fundamental energies or principles which govern the function of our bodies on the physical and emotional level. The three energies are known a Vata, pitta, and Kapha. [1] In normal state, they helps in the proper functioning of the body, but in abnormal state, they surely afflict the body by causing various kinds of disorders.[2] Pittena Saha Sambhooya\} spreads internally and externally\{Bahir-Antah Visarpatah\} and resulted in to 'Shitapitta i.e Ashayapkarsha Gati. This review of literature highlights study of Ashayapkarsha Gati in Samprapti of shiatpitta.

The disease produced at a place in the body where Pitta, Kapha are taken by Vata is same as the rain that occurs at the place where clouds are taken by the wind.[3] When Doshas are in Pravrudhha (increased) and Kshina (decreased), symptoms of Doshas are found to be in hyper-state and hypo-state respectively which is useful in assessment.[4] All the movements and activities in the body, take place due to Vata. Vata is the key force behind the physiological and pathological movement of the body elements. The disease produced at a place in the body where Pitta, Kapha are taken by Vata is same as the rain that occurs at the place where clouds are taken by the wind Doshagati is nothing but different Awastha (states) such as Kshaya, Vruddhi (vitiated), etc. Types of Doshgati are of four types, Koshtha-Shakha-Marmasthisandhi Gati, VruddhiKshaya-Sthana Gati, UrdhwaAdha-Tiryaka Gati[5] and Ashayapkarsha gati. Ashayapakarsha means displacement from original place. In this, the vitiated Vata Dosha displaces normal Pitta or Kapha from its place. Knowledge of Doshagati are important for proper diagnosis and treatment[6] .Normally Doshagati occurs two times in a day.[7,8] 'Madhavakara' described 'Shitapitta' and Udarda' as synonyms of each other [M. N. 50/41]; but then he quoted that 'Shitapitta' having 'Vatika Dominency' while 'Udarda' having 'Kaphaja Dominency'[M. N. 50/4]; and also mentioned specific character of 'Udarda' as 'Mandala' \{rashes\} having inflamed edges with depressed center [M. N. 50/5].In the classics 'Kotha' has been described as the 'Itchy red rashes covering major part of skin and chronic in nature' [M. N. 50/6].Though these three 'Shitapitta', 'Udarda' and 'Kotha' has been described as different entities, but they can be considered as different types of the 'Shitapitta' or 'Urticaria' as they all having same cardinal symptom i.e. 'Itchy red rashes on the skin' [M. N. 50].Starting from 'Nidana Sevana' to the 'Vyakti' of symptoms of disease.'Prakupita Vata and Kapha \{Pradushtau Kapha Marutau\} due to 'Shita Marutadi Nidana \{Shita Maruta Samsparshat\} - when being mixed with 'Pitta' PPittena Saha Sambhooya\} spreads internally and externally \{BahirAntah Visarpatah\} and resulted in to 
'Shitapitta

If the shitapita Samprapti is studied as a Ashayapkarsha gati as vitiation of Vata and Kapha Dosha in Pitta Sthan where Pitta is Prakrut, but Lakshanas are of Pitta Dosha Prominently. Then only the Chikitsak can plan treatment accordingly.

\section{Aim :-}

Conceptual study of Ashayapkarsha Gati w.s.t. Samprapati Vivechan of Shitapita.

\section{Objectives:-}

1. To study literature meaning of Gati, Ashayapkarshgati, shitapita Samprapti.

2. To correlate sitapita Samprapti and Ashayapkarshgati of Dosha.

\section{REVIEW OF LITERATURE}

Concept of Dosha The factors which are not only capable of vitiation but also having the nature of vitiating other factors of the body are known as Dosha.

1. Vata dosha(9)- word Vata is derived from ' $V a$ ' dhatu which indicates Gati -any movement or Gandha -smell. So the element in the body which performs all movements is termed as Vata.

2. Pittadosha - The word Pitta is derived from 'Tap' which is related to Santap-heat which is responsible for every form of digestion in the body.

3. Kapha dosha- The etymological derivation of the word Shlesama is formed from 'Shlish' which means being in close contact as in an embrace, to be in very close proximity which indicates conjugation between two cells or molecules in the body to form any structure.
Concept of Doshagati -

क्षयः स्थानं च वृद्धिश्च दोषाणां त्रिविधा गतिः।

ऊर्ध्वं चाधश्च तिर्यक्च विजेया त्रिविधाऽपरा | | १२२ | |

त्रिविधा चापरा कोष्ठशाखामर्मास्थिसन्धिषु।

इत्युक्ता विधिभेदेन दोषाणां त्रिविधा गतिः | | ११३ | |

च. सू. १७\११२,११३.[10]

Gati means movements. So Doshagati means the movement of Dosha. Chakrapanidatta stated that Doshagati is nothing but different Awastha (states) such as Kshaya, Prakopa (vitiated), etc.[10] Doshagati is a condition characterized by variation in the sites of Dosha depending on its equilibrium or unequilibrium state. In Equilibrium state, Doshas are present in their own site and performing normal functions whereas in unequilibrium state, Doshas are in hypo-state or hyperstate. Doshagati occurs in Roga-Marga (pathway of diseases) which.[11] includes Shakha (Sharirdhatus or body tissues excluding the Rasa Dhatu or plasma and including the Twak or skin), Koshtha (hollow organs and cavernous spaces or cavities of body) and Marma (vital organs). Dosha needs different treatment as per its site i.e. Koshthadi Sthanam (places like Koshtha). So the knowledge of signs and symptoms is important for deciding proper line of treatment.[12)

\section{Prakruta (Physiological) and Vikruta} (Pathological) Doshagati- In Prakruta Doshagati, Doshas are in equilibrium state and are present in their own site in the body so they perform their normal functions. But when these Dosha get vitiated, Doshagati becomes Vikruta.[13]

\section{Vruddhi, Kshaya, and Sthana (Normal)}


Gati- Diminution either in quantity or quality or action of Dosha or a combined diminution is considered as Kshaya(14). Increase either in quantity or quality or action of Dosha or a combined diminution is considered as Vruddhi. Sthana (place) refers to normal state of Dosha which maintains the physical and mental health. Kshayadi Gati describes specific Awastha of Dosha. [5]

Urdhwa (Upward), Adha (Downward), and Tiryaka (Oblique) Gati- Movements of vitiated Doshas in upward or downward direction to manifest disease are called as Urdhwa, Adha Gati respectively.[5] The movement of Dosha in oblique (Koshtha to Shakha) or transverse direction is known as Tiryaka Gati.

Koshtha, Shakha, and Marmasthisandhi (Vital Organs and Joints) Gati- Whenever the vitiated Doshas travel and get lodged in any of the three loci and manifest disease then the movement responsible is termed as Koshtha, Shakha or Marmasthisandhi Gati.[5]

\section{Ashayapakarsha Gati :-}

प्रकृतिस्थं यदा पित्तं मारुतः श्लेष्मणः क्षये।

स्थानादादाय गात्रेषु यत्र यत्र विसर्पति | ४५| |

तदा भेदश्च दाहश्च तत्र तत्रानवस्थितः।

गात्रदेशे भवत्यस्य श्रमो दौर्बल्यमेव च।|४६||

च. सू. १७/४५,४६. [15]

Ashayapakarsha means displacement from original place. In this, the vitiated Vata Dosha displaces normal pitta or Kapha from its place. This displacement of pitta and Kapha from its place causes various disorders due to imbalance of pitta and Kapha. The sites of pitta and Kapha become vacant, thus producing deficiency symptoms there in. In Ashayapkarsha, it is important to note that the pitta and Kapha are normal and not vitiated. It is the vitiated. Vata that displaces normal pitta and Kapha out of their places. Generally Ashayapkarsha is initiated by vitiated Vata Dosha. Vata aggravated due to the depletion of Kapha pulls or pushes normal pitta from its normal site ${ }^{15}$.

\section{Concept of Shitapitta- Nirukti of Shitapitta-}

There isn't any 'Vyutpatti' or 'Nirukti' for ' Shitapitta' available in any texts. But it comprises of two words i.e. 'Shita' and 'Pitta' which indicates that these is mainly vitiatioin of 'Vata and Pitta Dosha' in manifestation of 'Shitapitta'.

\section{PATHOGENESIS OF SHEETPITTA-}

Nidana' means the causative factors of disease. 'Nidana' having three effects in pathogenesis of disorder in pathogenesis of disorder i.e.

\section{Dosha Prakopa}

- Dushya Dushti and

Vaigunya.

.वरटीदष्टसंस्थानः शोथः सज्जायते बहिः ।

सकण्डूस्तोदबहुलश्छर्दिज्वरविदाहवान् ||३||

उदर्दमिति तं विद्याच्छीतपित्तमथापरे ।

वाताधिकं शीतपित्तमुदर्दस्तु कफाधिकः ||४||

Pathogenesis of sheetapitta is because of etiological factor Vata Dosha got prakopa and in turn leads to the vitiation of Pitta Dosha and Rakta Dushti, further spreading to extremities and leading to the manifestation of wheals (maculopapular 
rash), the sheetapitta.[16-17] The role of Vata Dosha in the manifestation was done by the presence of symptoms like dryness, pain and aggravating factors like exposure to the cold climate. Similarly, the role of pitta in the manifestation was done by the presence of symptoms like burning sensation and presence of itching indicates involvement of Kapha in the manifestation.

\section{Concept of Samprapti of shitapita-}

"Sheeta Maaruta Samsparshat Pradustou Kapha Maruthou"

"Pittena Saha Sambhooya Bahirantah Visarpatah"

\section{"Bahiranthah Iti Bahi Twachi Antah} Shoonitadou"

The impaired (vitiated) Vata, Pitta and Kapha being mixed up with one another lead to the formation of Amadosha very much like the yielding of toxic substance and cause pathological symptoms of Sheetapitta.

"Anye Doshebhyo Evathi Dushtebohyo Annonya Moorchanath" "Kodravebhya Vishasya Eva Vadantyamasya Sambhavam"

1) Due to Sheetamaaruta Samsparsha Vata and Kapha are concomitantly vitiated in the body and they mix with Pitta Dosha (which is already provocated due to its own causative factors). The vitiated Tridoshas spread internally into Raktadi Dhatus, take Sthana Samshraya in the Twak and thus manifestation of the disease Sheetapitta will take place.

2) In fact Dalhana points out the possibility of manifestation of Sheetapitta due to suppression of the urge for vomiting. Here it is imperative to deal with the mechanism of Chardinigrahana leading to cause 2020 September Special Issue Edition
Sheetapitta. Chardi occurs when the aggravated Kapha and Pitta move upwards by the Udana and Vyana Vayu ${ }^{18}$. Vamana eliminates Dushita Anna, Apakwa Pitta and Kapha from the body. Due to improper emesis or suppression of the urge for vomiting, the aggravated Kapha and Pitta will be retained and accumulate in the body as Ama. (Mala Sanchaya Roopi). "...... Kechit Malasanchayath" (Madhukosha of M.N.).

The term Mala used here applies to Kapha and Pitta which are not properly eliminated.Malas by definition encompass a variety of substances, produced in both normal and abnormal functioning of the body. By implication, vitiated Doshas are also included under the term Mala. In this connection Acharya Sushruta holds the point of view that, due to Chardi Nigraha, Vayu, in combination with aggravated Pitta and Kapha enters into the Tiryag Siras (vessels) which are transversely spread (Sirah Samprapadhya) and reaches Bahya Roga Marga (Samudduya Bahya Margam Prati). The regions of the skin, in which these above said morbid diathesis are deposited, produce Mandalas.

DISCUSSION -Ayurveda is designed for healthy and long lifespan. Dosha are basic principle of Ayurveda. and Doshagati is very important principle as it plays very important role in treatment. Movement of Dosha is called Doshagati. All the movements and activites in the body, take place due to Vata. Vata is the key force behind the physiological and pathological movement of body elements. Pitta, Kapha, Malas, Dhatus are all lame. They don't have independent movement in the body. w.jbino.com | Innovative Association 
They move from one place to the other only when mobilized or motivated by Vata. The knowledge of Ashayapkarsha will help the physician in understanding the pathological states of Doshas in a proper way to differentially diagnose the conditions and to implement comprehensive treatment.In Sheetpitta as per Ayurvedic science is a Tridoshaja Vyadhi. Initially, after Nidaan sevana (etiological factors) vitiation of Kapha and Vata takes place then they start to spread out in the whole body both externally and internally by mixing with Pitta. The Tridoshas travelling internally causes Dushti (pathogenesis) of Rasa and Rakta Dhatus after that Rasa vaha and Rakta vaha Sroto dushti occurs these on reaching to Vigna Twaka (sensitized skin) produce symptoms like Toda, Daha, Kandu, etc. Knowledge of Doshagati is also useful in deciding the line of treatment.

\section{CONCLUSION}

Charakacharya enriched Ayurveda with the knowledge of Doshgati. Its diagnostic and therapeutic usefulness with entirety is mentioned in Ayurvedic classics. Health can be summarized as Prakrut Gati of Doshas and Vikrut Gati defines illness. We cannot determine the nature of health without accounting Doshgati. The proper knowledge of Doshgati helps us to modify the daily \& seasonal regimen. Diagnosis and treatment of any disease cannot be complete without considering Ashayapkarsha Gati. So knowledge of Doshagati is very important in present era and in practice also.

\section{REFERENCES}

1. Sushruta. Sushruta Samhita, Vol. 1. Anantram Sharma, editor. 1st ed. Varanasi: Chaukhambha Surbharati Prakashan; Sutrasthana, 2008; 21/8; 179.

2. Charaka. Charaka Samhita, Vol. 1. Vidyadhar Shukla, Ravidatt Tripathi, editor. 1st ed. Varanasi: Chaukhambha Surbharati Prakashan; Vimansthana, 2007; 1/5: 548.

3. Sharangadhara. Sharangadhar Samhita. Bramhanand Tripathi, editor. 1st ed. Varanasi: Chaukhambha Surbharati Prakashan; Purvakhanda, 201 1; 5/43-44: 60.

4. Charaka. Charaka Samhita, Vol. 1. Vidyadhar Shukla, Ravidatt Tripathi, editor. 1st ed. Varanasi: Chaukhambha Surbharati Prakashan. Sutrasthana, 2007; 17/62: 264.

5. Charaka. Charaka Samhita (Ayurveda Dipika Commentary). Yadavaji Trikamji Acharya, editor.

1st ed. Varanasi: Chaukhambha Surbharati Prakashan. Sutrasthana, 2009; 17/112-113: 105.

6. Charaka. Charaka Samhita, Vol. 2. Vidyadhar Shukla, Ravidatt Tripathi, editor. Ist ed. Varanasi: Chaukhambha Surbharati Prakashan. Chikitsa sthana, 2007; 28/246247: 723.

7. Subhash Ranade, Paranjape GR. Rogavijnyan Vikrutivijnyan. 2nd ed. Pune: Prophishant Publishing House, 2013; 40.

8. Vagbhata. Ashtanga hrudayam. Brahmanand Tripathi, editor. 1st ed. Delhi: Chaukhamba Sanskrit Pratishthan; Sutrasthana, 2009; 1/8: 9.

2020 September Special Issue Edition | www.jbino.com | Innovative Association 
9. Shastri K.N; Chaturvedi G.N; Charaksamhita 8 ed. Chaukhambhabharti academy Varanasi, 1981.

10. Sushruta. Sushrut Samhita (Nibandhasangra vyakhya Commentary). Yadavaji Trikamji Acharya, editor. 1st ed. Varanasi: Chaukhambha Sanskrit samsthan. Sutra sthana, 2013; 21.

11. Madhavkara. Madhava Nidanam(Madhukosh Commentary), Vol.1. Upadhyaya, editor. Ist ed. Varanasi: Chaukhambha Sanskrit samsthan, 2012; 1/5: 21 .

12. Charaka. Charaka Samhita, Vol. 1. Vidyadhar Shukla, Ravidatt Tripathi, editor. Ist ed. Varanasi: Chaukhambha Surbharati Prakashan. Sutrasthana, 2007; 17/1 15: 272.

13. Sushruta. Sushrut Samhita (Nibandhasangra vyakhya Commentary). Yadavaji Trikamji Acharya, editor. Ist ed. Varanasi: Chaukhambha Sanskrit samsthan. Sutra sthana, 2013; 41/12: 183.
14. Charaka. Charaka Samhita, Vol. 1. Vidyadhar Shukla, Ravidatt Tripathi, editor. Ist ed. Varanasi: Chaukhambha Surbharati Prakashan; Sutrasthana, 2007; 17/45; 46.

15. Madhavakara. Madhava Nidanam(Madhukosh Commentary), Vol.1. Vijayrakshit, Shrikanthdatt, editor. 1st ed. Varanasi: Chaukhamba Sanskrit Samsthan, 2012; 1/5.

16.yadunandana upadhyaya madhav nidam by madhavakara with madhukosh sakrit commentary Varanasi ,chaukhama prakashn, reprint 2007.pp .202

17. Naredra Shastri, Madhav Nidana- Hindi translation delhi, motilal banarasidas pratisthan,reprint 2007 pp.200-201.

18.Vaidya lakshmikpatishastri, yogartnakar -Hindi translation, Varansi, Chaukhambha Prakashan. Uttarakhand, Sheetapittadinam Chikitsa prakarana verse 14, pp. 236 